\section{OPEN ACCESS}

Volume: 7

Issue: 3

Month: July

Year: 2019

ISSN: $2320-4168$

Received: 19.01.2019

Accepted: 14.06.2019

Published: 01.07.2019

Citation:

Vanitha Malarvizhi, P., and A. Angel. "A Comparative Study on Gold Loan Offered by Public Sector Banks and Non-Banking Financing Companies, Madurai." Shanlax International Journal of Commerce, vol. 7, no. 3, 2019, pp. 51-57.

DOI: https://doi.org/10.34293/ commerce.v7i3.398

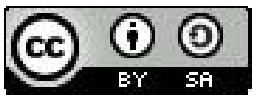

This work is licensed under a Creative Commons Attribution-ShareAlike 4.0 International License

\title{
A Comparative Study on Gold Loan Offered by Public Sector Banks and Non-Banking Financing Companies, Madurai
}

\author{
P.Vanitha Malarvizhi
}

Associate Professor in Commerce, Lady Doak College, Madurai, Tamil Nadu, India

\author{
A.Angel \\ Research Scholar in Commerce, Lady Doak College, Madurai, Tamil Nadu, India
}

\section{Abstract}

In today's modernized world everybody prefer to avail gold loan as it can be availed within the short durationfrom Banking institution and Non-Banking Financing institution where the preference to other credit was comparatively lesser as it consumes time.This research study is related to a comparative survey of the gold loan offered by Public sector Banks andNon-Banking Financing Companies in Madurai. This study is focused on the preference of the borrowers in availing the gold loan, the awareness level of borrowers about lending norms, factors influencing borrowers to avail the gold loan, problems faced by the borrowers while availing gold loan and satisfaction level of borrowers towards Public sector Banks and Non-Banking Financing Companies in availing gold loan. An attempthas been made to collect information from 107 respondents from the borrowers of gold loan from Public sector Banks and Non-Banking Financing Companies in Madurai city. The data collected using an appropriate questionnaire were analyzed and interpreted using statistical techniques, and also the testing of the hypothesis was done, and conclusions arrived at whether the theories were accepted or rejected.

Keywords: Banking Sector, Public Sector Banks, Non-Banking Financing Companies, Gold Loan, Gold loan margin, borrowers, Equated Monthly Installment, Bullet Repayment.

\section{Introduction}

The Indian Banking financial system plays a vital role in the economy. It performs numerous functions for the benefits of the people. The two significant features of the banking institution are accepting deposits and lending loans. The Indian Banking financial system has been classified into Banking institution and Non-Banking Financing Companies. They offer various types of credit to the people.

Themost preferred loan was a gold loan as the time taken to disburse the gold loan is less, and the procedure to acquire gold loan is also simple ${ }^{1}$.

The entry of organized sector in recent years, especially the entry of new players like Public sector banks and NBFCs into the field of gold loan, has made the business more profitable and it attracted full spread attention.Gold loans offered by NBFCsand Banks help the marginal sections of society in meeting their necessary funding requirements ${ }^{2}$.

\footnotetext{
1 A Comparative Study of some selected NBFCs and Commercial Banks," Indian Journal of Finance, Vol. 5 No.5 (Prasanta Paul 2011).

2 Nair Vinay and VermaGeeta (2010).Market Survey: "A study on the attitude towards Gold Loan, Mumbai” IndianResearch Review, Publication, p.7.
} 


\section{Objectives of the Study}

The following are the objectives of the study

i. To study the lending practices of gold loan followed by Public sector Banks and NBFCs.

ii. To analyze the preference of the borrowers towards Public sector Banks and NBFCs in availing the Gold Loan.

iii. To identify the factors influencing the borrowers to avail gold loan from Public sector Banks and NBFCs.

iv. To analyze the problems faced by the borrowers while availing gold loan from Public sector Banks and NBFCs.

v. To measure the level of satisfaction of the borrowers in availing gold loan provided by Public sector Bank and NBFCs.

\section{Scope of the Study}

The present study focused only on gold loan offered by Public sector Banks and Non-Banking Financing Companies. The study is limited to Madurai City only.

\section{Review of Literature}

Harini Subramanian $\left(\right.$ 2011) ${ }^{3}$ in her article titled “Gold loan: A More Precious Debt Option", she concentrated on finding whether there was any reason for borrowers to pledge gold jewelry to offer as collateral for personal loan. Shewas able to see that the amount of documentation and excessive verifications before borrowers' credit gets processed. Thus she concluded that if borrowers' prefer gold loan, they can easily avail gold loan from Bank before other loans.

Churiwal and Shreni (2012) In their study titled "Overview of Growing Gold Loan Demands," they highlightedon various aspects of Gold Loan from traditional pawnbroker to shifting of Gold Loan to NBFC. They analyzed important factors like rising in borrowing costs due to the removal of agricultural sector status on Loans. They finally concluded that NBFCs are growing through Gold Loan compare to organize banks.

Linda Mary Simon (2012) In her study titled "A Study on Customer Perception towards

3 HariniSubramani May (2010) "Gold loan: A more precious debt option”, Business Standard Publication
Services Provided by Public Sector Banksin the Coimbatore region," this article focused on the most preferred financial institution as per the services provided to customers. It revealed that NBFCs was providing better services to its customers than the public sector Banks. Thus it was concluded that public sector banks had a strong presence in the market, but in recent times they are facing stiff competition from NBFCs in the range and quality of services offered.

\section{Research Design and Methodology}

The data required for the study were collected from both primary and secondary sources. Primary data were collected through a structured questionnaire, and secondary data were collected from journals, magazines, theses, and enter the net. Even though the study has been confined with all public sector banks and NBFCs, the sample of respondents availed gold loan only fromthree PSBs namely State Bank of India, Canara Bank and Punjab National Bank and three Non-Banking Financing Companies namely Muthoot Finance Limited, Mannapuram Gold loan and IIFL Gold loan.

\section{Methodology of the Study}

This study is empirical.

- The analytical part of the study was based on primary data collected from the borrowers of a gold loan through a questionnaire. The data were collected and then analyzed to find the actual result.

\section{Sample Size}

The number of the sample size used for this study was 107 respondents. Out of 107 respondents, 62 had availed gold loan from Public sector Bank, and 45 respondents had availed from NBFCs. The data werecollected through a well-structured questionnaire.

\section{Sampling Design}

In the study, a simple random sampling method was used to collect the data from the borrowers of gold loan from Public sector Banks and NonBanking Financing Companies. 


\section{Period of the Study}

It defines the period taken for the completion of the study. For the study, the primary data and secondary data collected were covered a period of one academic year from June 2018- March 2019.

\section{Tools Used for Analysis}

The tools such as Percentage analysis,Likert scaling, Garret Ranking, Chi-square test, and ANOVA were used.

\section{Research Gap}

Earlier many researchers have undertaken a study about gold loan scheme, preference of gold loan as a debt option and comparative study between Public sector Bank and NBFCs in availing gold loan had been done by many researchers in other Districts of Tamil Nadu. But in this research, Comparative study has been made between Public sector Banks and Non-Banking Financing Companies in availing the gold loan in Madurai City.

\section{Scope for Future Research}

This research covered only a few Public sector Banks, and Non-Banking Financing Companies where future research can be conducted by selecting the sample of respondents availed gold loan from all the Public sector Banks and Non-Banking Financing companies in Madurai City.

\section{Limitations of the Study}

The study covered the borrowers of Public sector Banks and NBFCs who availed a gold loan. Buttherespondents selected at random confined with few Public sector Banks and Non-Banking Financing Companies.Therefore analysis was done considering those banks and NBFCs.

\section{Demographic Profile of the Respondents}

Demographic profile of the respondents includes the age of the respondents, gender, educational qualification, profession, and their monthly income. The following table shows the demographic profile of the respondents of both Public sector Banks and Non-Banking Financing Companies.
Table 1 Demographic Profile of the Respondents

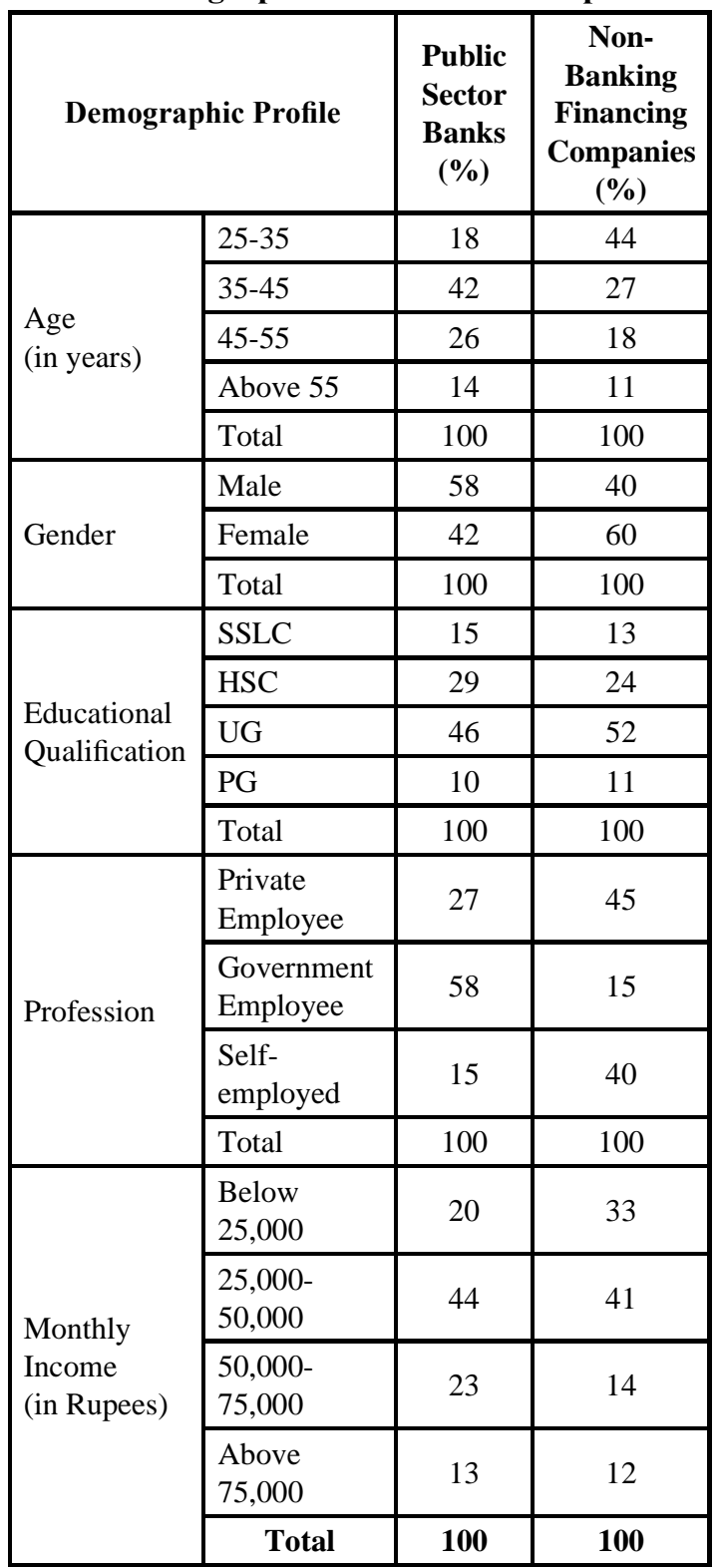

\section{Source: Primary Data}

Table 1 depicts the demographic profile of the respondents where $42 \%$ are within age group of $35-45$ (in years) in Public sector Bank, and $44 \%$ are within (25-35) in NBFCs, 58\% are male in Public sector Bank, and $60 \%$ are Female in NBFCs, $46 \%$ in Public sector Bank and 52\% in NBFCs completed UG Degree Programme, 58\% are Government employees in Public sector Bank and $45 \%$ are Private employees in NBFCs, $44 \%$ in Public sector Bank and $41 \%$ in NBFCs earn between 25,000-50,000 (in rupees). 


\section{Lending Practices of Gold loan followed by} Public Sector Bank and Non-Banking Financing

\section{Companies}

The lending practices of the gold loan include the gold loan schemes offered by different Public sector Banks and Non-Banking Financing Companies. These lending practices differ from each financial institution, and it also influences the borrowers in preferring such as Public sector Banks and NonBanking Financing Companies in availing a gold loan.

Table 2 Gold Loan Schemes of Public Sector Banks and NBFCs

\begin{tabular}{|c|c|c|c|}
\hline 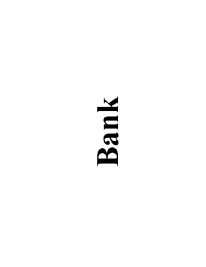 & 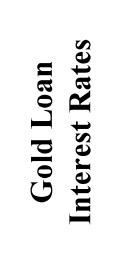 & 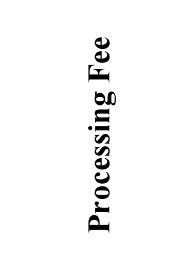 & 窇 \\
\hline $\begin{array}{l}\text { SBI Gold } \\
\text { Loan }\end{array}$ & $10.55 \%$ & $\begin{array}{l}0.50 \% \text { of the } \\
\text { loan amount } \\
\text { subject to a } \\
\text { minimum of } \\
\text { Rs. } 500\end{array}$ & $\begin{array}{c}36 \\
\text { Months }\end{array}$ \\
\hline Canara Bank & $12.00 \%$ & $\begin{array}{l}1 \% \text { of the } \\
\text { loan amount, } \\
\text { min Rs. } 1,000 \\
\text { and max Rs. } \\
5,000 \text { per } \\
\text { loan }\end{array}$ & $\begin{array}{c}12 \\
\text { Months }\end{array}$ \\
\hline $\begin{array}{l}\text { Punjab } \\
\text { National } \\
\text { Bank }\end{array}$ & $10.05 \%$ & $\begin{array}{l}\text { upfront fees } \\
\text { of } 0.70 \% \text { of } \\
\text { loan amount } \\
+ \text { taxes }\end{array}$ & $\begin{array}{c}12 \\
\text { Months }\end{array}$ \\
\hline ICICI Bank & $10.50 \%$ & $\begin{array}{l}1 \% \text { of the } \\
\text { Loan Amount }\end{array}$ & $\begin{array}{c}12 \\
\text { Months }\end{array}$ \\
\hline HDFC Bank & $11.50 \%$ & $1.5 \%$ & $\begin{array}{c}24 \\
\text { Months }\end{array}$ \\
\hline Axis Bank & $10.50 \%$ & $\begin{array}{l}0.25 \%-1 \% \text { of } \\
\text { Loan Amount }\end{array}$ & $\begin{array}{c}24 \\
\text { Months }\end{array}$ \\
\hline Yes Bank & $10.50 \%$ & $\begin{array}{l}\text { Nil to up to } \\
0.10 \%\end{array}$ & $\begin{array}{c}36 \\
\text { Months }\end{array}$ \\
\hline Federal Bank & $11.75 \%$ & Nil & $\begin{array}{c}12 \\
\text { Months }\end{array}$ \\
\hline $\begin{array}{l}\text { Muthoot Gold } \\
\text { Loan }\end{array}$ & $12.00 \%$ & $\begin{array}{l}0.25 \% \text { to } 1 \% \\
\text { of the loan } \\
\text { amount. }\end{array}$ & $\begin{array}{c}36 \\
\text { Months }\end{array}$ \\
\hline
\end{tabular}

\begin{tabular}{|l|c|l|c|}
\hline $\begin{array}{l}\text { Manappuram } \\
\text { Gold loan }\end{array}$ & $10.50 \%$ & $\begin{array}{l}\text { Rs. 10 (to } \\
\text { be paid at } \\
\text { the time of } \\
\text { settlement) }\end{array}$ & $\begin{array}{c}12 \\
\text { Months }\end{array}$ \\
\hline $\begin{array}{l}\text { IIFL Gold } \\
\text { Loan }\end{array}$ & $12.00 \%$ & Nil & $\begin{array}{c}11 \\
\text { Months }\end{array}$ \\
\hline
\end{tabular}

Source: https://www.bankbazzar.com dated as on 28th January 2019.

Table 2 depicts that the bank interest rates for public sector banks are lesser when compared to non-banking financing companies. The processing fees collected by banks and NBFCs will be charged as per the amount pledged.

\section{Awareness about Norms for Availing Gold Loan}

The overall awareness about gold loan features was found based on Likert scaling. Each factor was given weights, and the rank was given based on the mean score. The following table shows the mean score found using Likert scaling technique.

Table 3 Awareness Level about Gold Loan Norms

\begin{tabular}{|l|c|c|c|c|}
\hline \multirow{2}{*}{$\begin{array}{l}\text { Gold Loan } \\
\text { Features }\end{array}$} & \multicolumn{2}{|c|}{$\begin{array}{c}\text { Public Sector } \\
\text { Bank }\end{array}$} & \multicolumn{2}{c|}{ NBFCs } \\
\cline { 2 - 5 } & Rank & $\begin{array}{c}\text { Mean } \\
\text { Score }\end{array}$ & Rank & $\begin{array}{c}\text { Mean } \\
\text { score }\end{array}$ \\
\hline $\begin{array}{l}\text { Gold Loan } \\
\text { Amount }\end{array}$ & II & 4.56 & III & 4.10 \\
\hline $\begin{array}{l}\text { Gold Loan } \\
\text { Margin }\end{array}$ & VI & 2.45 & V & 3.18 \\
\hline $\begin{array}{l}\text { Rate of } \\
\text { Interest }\end{array}$ & I & 4.82 & II & 4.64 \\
\hline $\begin{array}{l}\text { Processing } \\
\text { Fees }\end{array}$ & V & 2.96 & VI & 3.01 \\
\hline $\begin{array}{l}\text { Document } \\
\text { Required }\end{array}$ & IV & 3.04 & IV & 3.89 \\
\hline $\begin{array}{l}\text { Time is } \\
\text { taken to } \\
\text { disburse } \\
\text { gold loan }\end{array}$ & III & 4.23 & I & 4.96 \\
\hline
\end{tabular}

Source: Computed Data

Table 3 evidenced that the majority were aware of the rate of interest in Public sector Banks and time is taken to disburse the gold loan in NBFCs, and they were aware least about gold loan margin in Public sector Banks and documents required in NBFCs. 


\section{Factors Influencing to avail Gold Loan}

From the following factors, Garrett ranking approach is applied to find out which factor has been influencing the borrowers the most to avail gold loan from Public sector Banks and Non-Banking Financing Companies in Madurai.

Table 4 Garrett Ranking for the Influencing Factors

\begin{tabular}{|l|c|c|c|c|}
\hline \multirow{2}{*}{ Factors } & \multicolumn{2}{c|}{$\begin{array}{c}\text { Public Sector } \\
\text { Bank }\end{array}$} & \multicolumn{2}{c|}{ NBFCs } \\
\cline { 2 - 5 } & Average & Rank & Average & Rank \\
\hline Highly Secured & 63.62 & 1 & 24.98 & 7 \\
\hline $\begin{array}{l}\text { Adequate } \\
\text { amount } \\
\text { provided }\end{array}$ & 52.23 & 3 & 45.67 & 1 \\
\hline $\begin{array}{l}\text { Mode of } \\
\text { repayment is } \\
\text { convenient }\end{array}$ & 35.67 & 6 & 32.16 & 4 \\
\hline $\begin{array}{l}\text { Low rate of } \\
\text { interest is } \\
\text { charged }\end{array}$ & 59.23 & 2 & 27.83 & 6 \\
\hline $\begin{array}{l}\text { Simple } \\
\text { procedure }\end{array}$ & 39.03 & 5 & 40.54 & 2 \\
\hline Purpose of loan & 46.78 & 4 & 36.49 & 3 \\
\hline Advertisements & 33.59 & 7 & 29.72 & 5 \\
\hline
\end{tabular}

\section{Source: Computed Data}

Table 4 inferred that highly secured was the most influencing factor to prefer Public sector Banks and the advertisement was the least influencing factor in Public sector Banks and the adequate amount provided was the most influencing factor and security was the least influencing factor to prefer NBFCs.

\section{Problems Faced while availing Gold Loan}

The issues faced by the borrowers were found using Likert scaling technique. The following table shows the mean score found using Likert scaling technology.

Table 5 Problems Faced while availing Gold

\section{Loan}

\begin{tabular}{|c|c|c|l|c|c|}
\hline \multicolumn{3}{|c|}{ Public Sector Banks } & \multicolumn{3}{c|}{ NBFCs } \\
\hline Problems & $\begin{array}{c}\text { Mean } \\
\text { Score }\end{array}$ & Rank & Problems & $\begin{array}{l}\text { Mean } \\
\text { Score }\end{array}$ & Rank \\
\hline $\begin{array}{l}\text { Delay in the } \\
\text { disbursement } \\
\text { of the loan }\end{array}$ & 3.96 & I & $\begin{array}{l}\text { The high } \\
\text { rate of } \\
\text { interest } \\
\text { charged }\end{array}$ & 3.99 & I \\
\hline
\end{tabular}

\begin{tabular}{|l|l|l|l|l|l|}
\hline $\begin{array}{l}\text { Rate of } \\
\text { interest } \\
\text { charged }\end{array}$ & 2.25 & IV & $\begin{array}{l}\text { Quality of } \\
\text { service }\end{array}$ & 2.64 & IV \\
\hline
\end{tabular}

Source: Computed Data

Table 5 depicts that delay in disbursement of the gold loan was the major problem in Public sector Banks, and the rate of interest charged was the least faced problem. The borrowers from NBFCs revealed that high rate of interest charged was the major problem faced and the quality of service provided was the least faced problem.

\section{Satisfaction Level towards Public sector Banks} and Non-Banking Financing Companies in availing Gold Loan

Satisfaction level of the borrowers towards Public sector Banks and Non-Banking Financing Companies in availing gold loan was found using Likert Scaling technique. The following table exposes the mean score summary which was found using Likert scaling technique

Table 6 Satisfaction level while availing Gold Loan

\begin{tabular}{|l|c|c|l|c|c|}
\hline \multicolumn{3}{|c|}{ Public Sector Banks } & \multicolumn{3}{c|}{ NBFCs } \\
\hline Statement & $\begin{array}{l}\text { Mean } \\
\text { Score }\end{array}$ & Rank & Statement & $\begin{array}{l}\text { Mean } \\
\text { Score }\end{array}$ & Rank \\
\hline $\begin{array}{l}\text { Safety to } \\
\text { property } \\
\text { pledged }\end{array}$ & 4.88 & I & $\begin{array}{l}\text { Adequate } \\
\text { amount } \\
\text { provided }\end{array}$ & 4.86 & I \\
\hline $\begin{array}{l}\text { Quality of } \\
\text { service }\end{array}$ & 2.02 & VIII & $\begin{array}{l}\text { Rate of } \\
\text { interest } \\
\text { charged }\end{array}$ & 1.67 & VIII \\
\hline
\end{tabular}

\section{Source: Computed Data}

Table 6 depicts that borrowers were highly satisfied with the safety to property pledged, and they were least satisfied with the quality of service provided in Public sector Banks. The borrowers of NBFCs were highly satisfied with the adequate amount provided, and they were least satisfied with the rate of interest charged.

Hypothesis (H0): There is no association between Gender, age, educational qualification, profession and monthly income of the respondents and satisfaction level of the borrowers in availing gold loan from Public sector Banks and Non-Banking Financing Companies. 
Hypothesis (H1): There is an association between Gender, age, educational qualification, profession and monthly income of the respondents and satisfaction level of the borrowers in availing gold loan from Public sector Banks and Non-Banking Financing Companies.

Table 7 Association between Demographic Factors and Satisfaction Level in availing Gold loan from Public sector Banks and Non-Banking Financing Companies

\begin{tabular}{|l|c|c|c|c|}
\hline \multirow{2}{*}{ Factors } & \multicolumn{2}{|c|}{$\begin{array}{c}\text { Public Sector } \\
\text { Banks }\end{array}$} & \multicolumn{2}{c|}{$\begin{array}{c}\text { Non-Banking } \\
\text { Financing } \\
\text { Companies }\end{array}$} \\
\cline { 2 - 5 } & $\begin{array}{c}\text { Chi- } \\
\text { Square } \\
\text { Value }\end{array}$ & $\begin{array}{c}\text { P- } \\
\text { Value }\end{array}$ & $\begin{array}{c}\text { Chi- } \\
\text { Square } \\
\text { Value }\end{array}$ & $\begin{array}{c}\text { P- } \\
\text { Value }\end{array}$ \\
\hline Gender & 22.574 & 0.001 & 26.341 & 0.006 \\
\hline Age & 59.260 & 0.009 & 42.409 & 0.002 \\
\hline $\begin{array}{l}\text { Educational } \\
\text { Qualification }\end{array}$ & 51.471 & 0.000 & 49.220 & 0.004 \\
\hline Profession & 38.416 & 0.07 & 33.494 & 0.000 \\
\hline $\begin{array}{l}\text { Monthly } \\
\text { Income }\end{array}$ & 69.348 & 0.000 & 51.249 & 0.002 \\
\hline
\end{tabular}

\section{Source: Computed Data}

If the p-value is less than $(0.5)$ is said to be significant at $5 \%$ level of significance, the null hypothesis is rejected, and the alternative theory is to be accepted.

Table 7 depicts that there is an association between the demographic profile of the borrowers with the satisfaction level in availing gold loan from Public sector Banks and Non-Banking Financing Companies.

\section{Findings and Suggestion Findings}

- Out of 107 respondents, 58\% preferred Public sector Banks and $42 \%$ of respondents preferred Non-Banking Financing Companies to avail a gold loan.

- More than $90 \%$ of respondents preferred to avail a gold loan when compared to other loans.

- The primary factor which influenced to avail gold loan from Public sector Banks were high security for the jewels pledged, and the main factor which influenced the respondents to prefer Non-Banking Financing Companies was the adequacy of the amount provided for treasures pledged.

- The borrowers of Public sector Banks were highly satisfied with the safety for the security pledged, and they are dissatisfied with the quality of services provided.

- The borrowers of Non-Banking Financing companies were highly satisfied with the adequacy of the amount provided for jewels provided, and they are dissatisfied with the higher rate of interest charged,

\section{Suggestions}

The Public sector Banks should provide an adequate amount of gold loan, similar to NonBanking Financing Companies. Therefore the preference of borrowers towards Public sector Banks increases in availing a gold loan. Even though the rate of interest charged is high in Non-Banking Financing Companies, the borrowers prefer to avail gold loan from NBFCs as the time is taken to disburse the gold loan is less.

Similarly, the Public sector Bank should try to disburse the gold loan within a short duration.Even though the gold loan amount provided is less, the borrowers still prefer to avail gold loan from Public sector Banks because of the security provided for the gold jewels pledged. Therefore Non-Banking Financing Companies should also ensure safety for the gold jewels guaranteed by installing a safety system. The quality of services provided by NonBanking Financing Companies is too good towards borrowers while lending the gold loan. Similarly, the Public sector Banks should improve the quality of services while giving gold loan to the borrowers.

\section{Conclusion}

Thus it can be concluded that gold loan has become one of India's fastest growing businesses. It was obvious that the majority of people prefer Public sector Banks when compared to NBFCs irrespective of the attracting features followed by NBFCs. This is because Public sector Banks ensures security for the gold ornaments pledged, and the rate of interest charged is also less. But the preference towards NBFCs in availing gold loan also is increasing now a day as they provide an adequate amount for the gold 
jewels pledged and the time taken to disburse the gold loan is even less. Therefore the borrowers meet out their expenses at the time of emergency. Thus gold loans offered by NBFCsandPublic sector Banks help the marginal sections of society in meeting their necessary fund requirements whenever required.

\section{References}

Churiwal Amit and Shreni Ashish August. Surveying the Indian Gold Loan Market, Cognizant 20-20 insights, 2012

Nair Dnaynesh, N. "Changing Consumer Perception Driving India's Organized Gold Loan Market, Mumbai, India", International Research Review, para 7, 2012.
Prasanta Paul, "A Comparative Study of some selected NBFCs and Commercial Banks," Indian Journal of Finance, vol. 5, no.5, 2011 p. 13-22, 42 .

Sharma. BP. "The role of commercial bank in the developed economy," S. Chand \& Co. Ltd, New Delhi, 2011.

http://www.shanlaxjournals.in/wp-content/uploads/ ASH_V5_N3_054.pdf

https://www.paisabazaar.com/bank/gold-loanprocedure/ dated on 6th February 2019.

https://www.paisabazaar.com/gold-loan-emicalculator/ dated on 3rd February 2019.

https://www.paisabazaar.com/gold-loan/goldloan-from-public-banks-and-nbfcs-in-india/ dated on 9th January 2019.

\section{Author Details}

Dr.P.Vanitha Malarvizhi, Associate Professor in Commerce, Lady Doak College, Madurai, Tamil Nadu, India

Email ID: vanithamalarvizhi@ldc.edu.in

Ms.A.Angel, Research Scholar in Commerce, Lady Doak College, Madurai, Tamil Nadu, India

Email ID: jessijasmine25@gmail.com 